\title{
Connoisseurship, Consumption, Company, and James Brydges, First Duke of Chandos, 1705-13
}

\author{
Aaron Graham
}

\begin{abstract}
A B STRACT Between 1705 and 1713, James Brydges (later the first Duke of Chandos) was both a public official and a private collector and connoisseur. These roles have been seen as separate and even incompatible, as the personal connections required for collecting artworks from Europe cut across the impersonal, bureaucratic standards expected from officials. Drawing on Brydges's extensive correspondence, Aaron Graham argues that the process of collecting and connoisseurship in fact made him a far more effective public official. Recent work has shown that public service in this period often required officials to cultivate relationships with the merchants and financiers who acted as contractors for state business. A shared process of collecting, appreciating, and consuming goods, including such mundane items as wine, helped to strengthen connections. KEY WORD S: consumption and eighteenth-century social networks; trust within early modern commercial networks; sociability; Jan Hallangias; Charles Medlycott
\end{abstract}

N EARLY IN OCTOBER 1709, the Custom House in London was visited by the Hon. James Brydges, later the first Duke of Chandos, who went to see two paintings by Gerrit Dou that his trusted agent in Holland had bought for him at a cost of 2,050 guilders, or about $£ 200 .{ }^{1}$ He also collected from the cellars of the Custom House several hogsheads of wine shipped over to him by the same agent. Brydges was probably relieved "to get it safe out of the hands of those privateers, I mean the Custom House officers," though perhaps this time they were "so civil," as indeed they

1. Stowe Papers (hereafter ST) 58 Vol. 5, fols. 1-2, 46, 103; ST 57 Vol. 3, fols. 8o, 81, Huntington Library, San Marino, California (hereafter HL); Koenraad Jonckheere, The Auction of King William's Paintings, 1713: Elite International Art Trade at the End of the Dutch Golden Age (Amsterdam, 2008), 48; C. H. Collins Baker and Muriel I. Baker, The Life and Circumstances of James Brydges, First Duke of Chandos, Patron of the Liberal Arts (Oxford, 1949), 71, 74.

Pp. 539-557. (C) 2017 by Henry E. Huntington Library and Art Gallery. IssN 0018-7895 | E-ISSN 1544-399x. All rights reserved. For permission to photocopy or reproduce article content, consult the University of Pennsylvania Press Rights and Permissions website, http://www.upenn.edu/pennpress/about/permissions.html. 
were six months later, "as to let me have a taste of it." 2 No doubt the visit was also a pleasant distraction from his official duties, but one that historians have argued was increasingly incompatible with them. Since John Brewer's landmark study The Sinews of Power (1988), work by Michael J. Braddick, Roger Morriss, and others has argued that the long eighteenth century in Britain saw a shift toward impersonal, bureaucratic structures that worked because they rejected the corrupt official culture of gifts and favors of the seventeenth century. ${ }^{3}$ In fact, as this episode suggests, overlaps persisted between public duties and private interests, and more recent work by myself and others has argued that the British fiscal-military state continued to depend on its connections with private contractors. To exploit these connections effectively, officials had to engage with merchants on their own terms, through a culture of personal trust that was leavened with "corrupt" personal relationships. 4 This essay puts this assertion to the test, arguing that connoisseurship, consumption, and company helped Brydges and his agents build stronger networks.

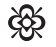

Between 1705 and 1713, Brydges was paymaster of the forces abroad, with overall responsibility for paying British and allied troops fighting in Europe during the War of the Spanish Succession (1702-13). ${ }^{5}$ At various points in his life he was also a politician, ${ }^{6}$ electoral manager, 7 financial speculator, ${ }^{8}$ commercial investor, 9 property

2. HL, ST 57 Vol. 1, fol. 162; Vol. 3, fols. 228, 233.

3. See a recent survey of this literature in Aaron Graham and Patrick Walsh, introduction to The British Fiscal-Military States, 1660-c.1783, ed. Graham and Walsh (London, 2016), $1-25$.

4. Graham and Walsh, introduction. See in particular Gordon Bannerman, Merchants and the Military in Eighteenth-Century Britain: British Army Contracts and Domestic Supply, 1739-1763 (London, 2008); and R. J. B. Knight and Martin Wilcox, Sustaining the Fleet, 1793-1815: War, the British Navy and the Contractor State (Woodbridge, U.K., 2010).

5. Aaron Graham, Corruption, Party, and Government in Britain, 1702-1713 (Oxford, 2015), 95-97; Baker and Baker, Chandos, 44-61.

6. E. Cruickshanks, S. Handley, and D. W. Hayton, The House of Commons, 1690-1715, 5 vols. (Oxford, 2002), 3:377-83.

7. R. G. Schafer, "A By-Election in a Rotten Borough," Huntington Library Quarterly 17, no. 4 (1954): 397-405; Clyve Jones, "James Brydges, Earl of Carnarvon, and the 1717 Hereford By-Election: A Case Study in Aristocratic Electoral Management," Huntington Library Quarterly 46, no. 4 (1983): 310-20.

8. Baker and Baker, Chandos, 206-20, 337-64; Antoin E. Murphy, Richard Cantillon: Entrepreneur and Economist (Oxford, 1986), 73-82, 125-27, 175-83; Koji Yamamoto, "Beyond Rational vs Irrational Bubbles: James Brydges the First Duke of Chandos during the South Sea Bubble," in Le crisi finanziarie: Gestione, implicazioni sociali e conseguenze nell'età preindustriale / The Financial Crises: Their Management, Their Social Implications and Their Consequences in Pre-Industrial Times (Florence, 2016), 325-58.

9. Matthew David Mitchell, "Legitimate commerce' in the Eighteenth Century: The Royal African Company of England under the Duke of Chandos, 1720-1726," Enterprise 
developer, ${ }^{10}$ and scientific patron, ${ }^{11}$ though these aspects have all been examined in isolation from his activities as a collector. Although Brydges was derided by contemporaries and historians as the inspiration for Timon in Alexander Pope's Epistle to Burlington, and thus an exemplar of bad taste, recent work by Susan Jenkins and Koenraad Jonckheere has confirmed earlier arguments by Collins and Muriel Baker that he also deserves to be taken seriously as a cultural patron and connoisseur, not least because Pope himself denied that he had based his portrait of Timon on Brydges. ${ }^{12}$ Like many British diplomats and officials in this period, Brydges collected paintings, tapestries, sculptures, and artwork from inclination as well as ambition, and he relied on a network of agents across Europe who specialized in this task. ${ }^{13}$ Jonckheere has described them as solliciteurs-culturel, by analogy with the military agents, or solliciteurs-militair, who managed finances for German and Dutch regiments in this period. Indeed, he argues that "this network of cultural agents was grafted onto the existing web of solliciteurs-militair," who were trusted not only to represent their principals' interests but also to understand their tastes in choosing artwork and luxuries. ${ }^{14}$

Connoisseurship, collecting, finance, and warfare therefore overlapped, with networks of military and cultural agents as the bridge or common factor. These networks were, in turn, held together by trust, like all commercial networks in early modern society. Defined broadly as the expectation that mutual obligations would be duly honored and discharged, owing to a shared set of interests, trust enabled merchants to overcome the problems of distance and communication by devolving decisions to partners or agents who could be expected to keep these mutual interests at heart. Extensive work in the social sciences has stressed the role of agents in helping to overcome informational asymmetries, where an employer lacks the information to make an informed commercial decision and delegates it to the agents on the ground, and the role of trust in turn in addressing the resulting principal-agent problems, where the employer might not be in a position directly to supervise and control the

and Society 14, no. 3 (2013): 544-78; William A. Pettigrew, Freedom's Debt: The Royal African Company and the Politics of the Atlantic Slave Trade, 1672-1752 (Chapel Hill, N.C., 2013), 165-72. 10. Baker and Baker, Chandos, 221-35, 296-336; R. S. Neale, Bath 1680-1850: A Social History (London, 1981), 130-49; P. G. M. Dickson and John Vincent Beckett, "The Finances of the Dukes of Chandos: Aristocratic Inheritance, Marriage, and Debt in Eighteenth-Century England," Huntington Library Quarterly 64, nos. 3-4 (2001): 315-34.

11. Larry R. Stewart, The Rise of Public Science: Rhetoric, Technology, and Natural Philosophy in Newtonian Britain, 1660-1750 (Cambridge, 1992), 320-23.

12. Baker and Baker, Chandos, 65-92; Susan Jenkins, Portrait of a Patron: The Patronage and Collecting of James Brydges, 1st Duke of Chandos (1674-1744) (Aldershot, U.K., 2007); Jonckheere, Auction, 132-34.

13. Jonckheere, Auction; Koenraad Jonckheere, “The 'Solliciteur-Culturel': Some Notes on Dutch Agents and the International Trade in Art and Applied Arts," De Zeventiende Eeuw 24, no. 2 (2008): 162-80; Helen Jacobsen, Luxury and Power: The Material World of the Stuart Diplomat, 1660-1714 (Oxford, 2011).

14. Jonckheere, Auction, 217; Jonckheere, "Solliciteur-Culturel," 176-78. 
agent's behavior. Francesca Trivellato and others have shown that informal cultural structures such as kinship, friendship, religion, and regional identity could all help to reinforce trust by creating a sense of shared interests and embedding the link between the principal and agent in wider structures that reward good behavior and punish abuses. ${ }^{15}$ Trust and a sense of shared obligation could also be built up by exchanging correspondence, civilities, and gifts as part of the gift economy described by Marcel Mauss in anthropological terms and successfully applied by Natalie Zemon Davis, Felicity Heal, and others to gift-giving practices in the early modern world. ${ }^{16}$

Trust was therefore constructed by sets of social or cultural connections and by the exchange of material objects. But this essay draws together recent studies of material culture and "consumption" to argue that material objects had cultural resonances and that social and cultural connections were expressed through material objects, which in turn informed how trust was created. In other words, the value of the gifts exchanged between principals and agents to create shared obligations cannot be fully understood without considering that such mundane items were also aesthetic objects whose symbolic qualities informed the strength of these obligations. As Helen Berry argued more than a decade ago, historians must consider "how goods were acquired ... [and] the social interactions (in addition to the economic means and processes) which were required to procure them"-not just the act of consumption itself, which has been studied in detail by John Brewer, Linda Levy Peck, Maxine Berg, and others in their work on the "consumer revolution." 17 This latter work has mainly focused on the elite consumption of luxury items in the seventeenth century, which was often too limited for the kind of "thick" description that research into consumerism requires, or the popular consumption of manufactured items in the

15. For a historiographical overview of trade networks and trust, see Aaron Graham, "Review Article: Mercantile Networks in the Early Modern World," Historical Journal 56 (2013): 279-95. Recent studies using this approach include Francesca Trivellato, The Familiarity of Strangers: The Sephardic Diaspora, Livorno, and Cross-Cultural Trade in the Early Modern Period (London, 2009); David Hancock, Oceans of Wine: Madeira and the Emergence of American Trade and Taste (London, 2009); and Xabier Lamikiz, Trade and Trust in the EighteenthCentury Atlantic World: Spanish Merchants and Their Overseas Networks (London, 2010). For theoretical studies of trust informed by the social sciences, see the essays in Handbook of Trust Research, ed. Reinhard Bachmann and Akbar Zaheer (Cheltenham, U.K., 2006); and Organizational Trust: A Reader, ed. Roderick Kramer (Oxford, 2006).

16. For an excellent summary of this literature, see Felicity Heal, The Power of Gifts: Gift Exchange in Early Modern England (Oxford, 2014), esp. 4-10. For examples, see Natalie Zemon Davis, The Gift in Sixteenth-Century France (Oxford, 200o); and Ilana Krausman Ben-Amos, The Culture of Giving: Informal Support and Gift-Exchange in Early Modern England (Cambridge, 2008), 45-81, 145-305.

17. Helen Berry, "Polite Consumption: Shopping in Eighteenth-Century England," Transactions of the Royal Historical Society 12 (2002): 376-77. See also Linda Levy Peck, Consuming Splendor: Society and Culture in Seventeenth-Century England (Cambridge, 2005); the essays in Consumption and the World of Goods, ed. John Brewer and Roy Porter (London, 2003); and Maxine Berg, Luxury and Pleasure in Eighteenth-Century Britain (Oxford, 2005). 
eighteenth century, which lacked the same elements of connoisseurship and aesthetic appreciation. This essay draws on Sara Pennell's suggestion that highly ephemeral consumables such as wine were "important 'containers' of and for consuming" that can be analyzed as pieces of material cultures with aesthetic qualities. I argue that this increased their impact within the moral economy of gifts and trust. ${ }^{18}$

The actual process of consuming these objects served a similar purpose, because the context in which they were consumed could increase their effects. Jon Stobart, Sara Pennell, and Helen Berry have demonstrated, for instance, how retailing and shopping were informed by their cultural contexts. Pennell has concluded that "the exploration of physical and imaginary consuming 'spaces' ... offers historians of consumption many provocative, productive lines of investigation." 19 One such line of investigation, an important and useful one, has been recent work on "company." Studies of early modern alehouse culture by Phil Withington and Mark Hailwood and coffeehouse culture by Brian Cowan have shown how cultural and social rituals at the point of consuming beer or coffee helped to strengthen social relationships and thus, by implication, trust. ${ }^{20}$ Peter Clark has suggested that wine served very similar purposes in clubs and societies, especially through the practice of offering frequent toasts or "healths." David Hancock has recently noted how importers of Madeira wine into North America worked to develop a new culture of "wine hospitality" that brought together an appreciation for the wine itself with a culture of sociability informed by new rituals of consumption and the material objects such as glassware necessary to support them. ${ }^{21}$

This essay is divided into three sections, each drawing on key themes in this scholarship. The first examines the overlap between connoisseurship and collecting, demonstrating that Brydges applied aesthetic judgment to a wide range of commodities acquired by his agents, in ways predicted by Pennell, Berry, and others. These commodities ranged from ceramic tiles and expensive textiles used to furnish his house at Canons to horses, garden ornaments, watches, and snuffboxes.

18. Sara Pennell, "Consumption and Consumerism in Early Modern England," Historical Journal 42, no. 2 (1999): 561-62.

19. Berry, "Polite Consumption"; Pennell, "Consumption and Consumerism," esp. 555-57; Jon Stobart, Sugar and Spice: Grocers and Groceries in Provincial England, 1650-1830 (Oxford, 2013); Nancy Cox, The Complete Tradesman: A Study of Retailing, 1550-1820 (Farnham, U.K., 2000).

2o. Phil Withington, "Company and Sociability in Early Modern England," Social History 32, no. 3 (2007): 297-307; Mark Hailwood, Alehouses and Good Fellowship in Early Modern England (London, 2014); Brian W. Cowan, The Social Life of Coffee: The Emergence of the British Coffeehouse (London, 2005).

21. For toasting, sociability, and trust, see Peter Clark, British Clubs and Societies 1580-180o: The Origins of an Associational World (Oxford, 2000), 163-64, 226-27. For "wine hospitality," see Hancock, Oceans of Wine, 337-84, 387-89; and also Paul Duguid, "Networks and Knowledge: The Beginning and End of the Port Commodity Chain, 1703-1860," Business History Review 21, no. 2 (2005): 109-18. 
This discernment was understood by his agents, who took care to highlight the quality of the goods they sent. The second section demonstrates that Brydges's attention extended even to the most ephemeral of consumables, as described by Pennell, such as wine, tobacco, and cider, which carried their own cultural - and even politicalovertones. Brydges and his agents took considerable care to tailor the items they sent to the tastes of the persons who received them. Finally, the third section deploys the theories of company to demonstrate that Brydges and his agents continually worked to create trust by consuming these items in certain ways, as part of a shared culture of hospitality and sociability. The essay concludes by arguing that the networks created by Brydges as public official and private collector overlapped and intersected in this period, cemented by the trust created through a shared appreciation for these items, with important implications for studies of politics and society.

\section{cocs}

Brydges was exceptional mainly for the range and extent of his collecting rather than for the mere fact of it. As Helen Jacobsen has shown, many well-born British diplomats in this period acquired artworks of all sorts from overseas, not only to create suitable public personas but also to reflect genuine interest and aesthetic sensibility. ${ }^{22}$ Merchants also invested in such items, though this has usually been linked to their desire for social advancement and cultural self-fashioning. "Collecting art, like building houses," argues Hancock, "reflected, enhanced and reinforced the[ir] ... emerging gentility." 23 As noted above, collectors often relied on agents or solliciteurs-culturel to buy artwork on their behalf, a process that was both commercial and personal, since it required the employer to trust the agent's financial honesty and aesthetic judgment. "Good personal contacts and confidentiality were essential," Jonckheere concludes, "[since] the pre-financing of political, military and cultural investments for the foreign princes and aristocrats by agents was a matter of trust." 24 As a result, some British collectors used their existing diplomatic or administrative networks to purchase artwork or other objects. Diplomats used their secretaries or diplomatic agents, for example, whereas the perennial bureaucrat William Blathwayt used his contacts at the Board of Trade and the War Office to secure exotic American hardwoods and vast amounts of Dutch artwork, tapestries, and goods. ${ }^{25}$ Brydges

22. Jacobsen, Luxury and Power, 65-90, 119-230. See also Maya Jasanoff, Edge of Empire: Lives, Culture, and Conquest in the East, 1750-1850 (New York, 2005), for a later period. 23. David Hancock, Citizens of the World: London Merchants and the Integration of the British Atlantic Community, 1735-1785 (Cambridge, 1995), 347-51, and, more broadly, the references in note 17 above.

24. Jonckheere, "Solliciteur-Culturel," 184.

25. Gertrude Ann Jacobsen, William Blathwayt, a Late Seventeenth Century English Administrator (Oxford, 1932), 61-63; Lisa Jardine, Going Dutch: How England Plundered Holland's Glory (London, 2008), 260-62; Jacobsen, Luxury and Power, 88, 102-3. 
not only employed trusted agents within his own Pay Office networks for the same purposes but also used the process of collecting itself to create personal trust that strengthened them in turn, and made them better instruments of public policy.

Both Jonckheere and Jenkins have shown that Brydges purchased artwork through his agents in the Low Countries between 1705 and $1713 .{ }^{26}$ The linchpins were John Drummond and Walter Senserf, merchants in Amsterdam and Rotterdam respectively, who not only supplied financial and commercial assistance to the army in the Low Countries but also dispatched large a mounts of artwork and other luxuries from the Continent. ${ }^{27}$ More pieces were bought by Sir Matthew Decker, Brydges's trusted banker and stockbroker. After the war ended in 1713, Brydges bought further paintings in Paris through Drummond, Decker, and other former agents such as Anthony Hammond and Richard Cantillon, as well as sculptures, tapestries, drawings, books, and other expensive cultural artifacts requiring a degree of aesthetic judgment. This in itself was an important statement of trust, since the artwork that they brought for Brydges would reflect on his own judgment when it was placed on display at Canons, while his agents recognized that they had an opportunity to demonstrate their skill and judgment, and their shared aesthetic sensibilities. "A clever client," Jacobsen notes, "knew that gifts were about more than economic value: they should also further the stature and distinction of his patron." 28 This built on the trust already implicit in these financial networks, since Brydges likewise relied on these men to discharge their public duties efficiently and honestly, and to support the private-and highly illegal-financial opportunities that he offered to trusted military agents. ${ }^{29}$ As Jonckheere notes, though, "the elite trade in luxury goods, the political expenses of foreign princes, the financing of the military and the Dutch haute finance were fused." Widening the focus to other goods shows that Brydges used his public officials in the same way, building on the trust they already shared but using the process of private collecting to reinforce it. 30

In April 1710, for example, Brydges asked his deputy in Turin, the diplomat William Chetwynd, to secure fashionable Genoese damask and velvet for the bed, hangings, and chairs of two rooms at Canons. "Still the most highly prestigious and expensive in Europe," according to Jacobsen, this fabric would advertise his taste to anyone who visited. Brydges trusted Chetwynd so strongly that he was prepared to leave the choice of color entirely to him, "whom I know to have an excellent

26. Jonckheere, "Solliciteur-Culturel," 162-80; Jonckheere, Auction, 215-20.

27. Jonckheere, Auction, 134-35, 139-50; Jonckheere, "Solliciteur-Culturel," 161-71; Jenkins, Portrait, 138-40; Baker and Baker, Chandos, 75-81. For Brydges's official links to these agents, see Graham, Corruption, and below.

28. Jacobsen, Luxury and Power, 68-69.

29. Graham, Corruption, 108-36, 140-50, 160-63, 210-25.

30. Jonckheere, "Solliciteur-Culturel," 171-79. 
fancy." 31 Chetwynd was hesitant, replying that "everyone has a different genius for colour [and] I could wish you would name your favourite one," but Brydges's trust was unshakeable, and he repeated in September that he "question[ed] not but your fancy will be approved by everyone who sees it." He also asked Jan Hallangias, the solliciteur-militair for the Landgrave of Hesse-Kassel and one of his own most trusted informal agents, to secure 10,00o delftware ceramic tiles from Amsterdam. ${ }^{32} \mathrm{Hal}$ langias likewise doubted his own judgment, though, and wished that Brydges "had been more particular about the tiles.... it was necessary to know Your Honour's pleasure what sort of blue paintings were most acceptable, if figures of men, beasts, flowers, etc." These two episodes show that Brydges and his agents appreciated the importance of good judgment. His agents therefore hesitated, knowing that this might make or break the relationship, whereas Brydges seems to have seen it as a flattering demonstration of his existing trust in them. Connoisseurship and collecting could therefore arise, as Jonckheere has argued, out of existing military and financial relationships.

The process also worked in reverse, and the honesty and judgment that private agents displayed as they bought goods for Brydges, as solliciteurs-culturel, made him more willing to trust them as solliciteurs-militair. This can be seen clearly in his purchase of clothing and textiles in the Low Countries, which was as much a marker of both wealth and taste as the artwork he collected, and required him to trust the judgment of his agents. 33 He relied heavily, for example, on Henry Cartwright, the deputy paymaster in Antwerp, who discharged his duties there with honesty and efficiency and helped Brydges operate his private financial schemes.34 Brydges also asked Cartwright to purchase lace from Antwerp for shirts in 1707 and 1708, and in 1712 he sent another request for lace and a dozen pairs of ruffles, specifying that they be in the latest fashion but otherwise deferring to Cartwright's judgment. Cartwright's counterpart in Amsterdam, Benjamin Sweet, was not trusted by Brydges and so had only occasional commissions. Brydges instead relied on Sweet's clerk and cousin-in-law George Murray, even though Brydges initially thought Murray would be loyal to Sweet: he told Sweet that Murray was a person "who [Sweet] could entirely rely on as knowing him to be fix't in your interest." 35 A series of small private requests for items such as lace helped to develop trust, and eventually Brydges charged Murray's wife

31. HL, ST 57 Vol. 5, fols. 66, 241; Vol. 7, fols. 184-85, 251; ST 58 Vol. 7, fol. 223; Jacobsen, Luxury and Power, 92-104, 176-79; Baker and Baker, Chandos, 65, 125.

32. HL, ST 57 Vol. 2, fols. 81-82; Vol. 4, fol. 11; ST 58 Vol. 3, fols. 121, 149, 158; Baker and Baker, Chandos, 65, 217, 447. For Hallangias, see Graham, Corruption, 101, 103, 112, 118-20, 124-28, 212-13.

33. For an overview of consumption, clothing, fashion, and display, see, for example, Berg, Luxury and Pleasure, 249-57; and Jacobsen, Luxury and Power, 4-8.

34. HL, ST 57 Vol. 1, fol. 65; Vol. 2, fol. 48; ST 58 Vol. 2, fol. 42; Graham, Corruption, 101-3, 108, 129-36, 202-3.

35. HL, ST 57 Vol. 9, fols. 147, 191; Graham, Corruption, 128. 
Mary with a delicate commission to purchase a large bolt of silk for his wife's mantua or gown, "not too rich but genteel and handsome." 36 The trust was so strong that it survived even when Brydges dismissed Sweet in 1712, and Murray went on to serve as Brydges's agent in the Mediterranean. 37 Private trust and tastes therefore eventually translated into public duties and responsibilities.

Recognizing the connection between the two, agents therefore took personal care to purchase gifts or discharge private commissions from Brydges in ways that reflected well on their own judgment. In November 1707, for example, Brydges thanked his agent in Barcelona for "the finest feathered bird I ever saw, and [it] speaks the most." 38 The following year he asked his deputy in Barcelona, John Mead, to purchase a horse for him. 39 Mead owed his position to his uncle, Brydges's private goldsmith-banker, and told him in July 1711 that he had taken several years over the commission, "as a small acknowledgement of the many obligations I owe [Brydges]." He bought the horse in 1709 but had been "for some time in suspense whether he was worthy of Mr Brydges' acceptance, an accident happening to him ... but my Lord Duke of Argyll and several others being extremely taken with him ... I was persuaded to come over this difficulty by their approbation." 40 This letter was shown by Mead's uncle to Brydges, ensuring that Brydges recognized the effort that had gone into the purchase, while also reinforcing Mead's judgment in horseflesh by noting that others had agreed with his choice. An agent in Lisbon, Brydges's deputy Thomas Morrice, followed up an earlier gift in 1710 with a pair of Barbary hens, a species of guinea fowl. 41 "[They are] a great ornament to my garden," Brydges noted, "and admired by all who see them," adding in the same letter that he had served Morrice's interests in London in return by recommending him to the Treasury. Gifts helped to build trust and shared obligations in the ways suggested by Heal and others, and so agents took particular care to use them to advertise their taste and judgment.

At a more commonplace level, even exchanges of snuff and food could help cement trust between Brydges and his deputies or agents, since agents presented them in much the same way. Snuff was of varying quality, for instance, and it was often mixed with flavorings, colorings, and essences that required careful selection. $4^{2}$

36. HL, ST 57 Vol. 2, fol. 82; Vol. 4, fol. 159; Vol. 5, fol. 164. On the cost of silk, see Jacobsen, Luxury and Power, 177-79.

37. HL, ST 57 Vol. 7, fol. 49; Vol. 10, fol. 51; ST 58 Vol. 11, fol. 259; Vol. 12, fols. 243-45, 268-69; Aaron Graham, "Auditing Leviathan: Corruption and State Formation in Early Eighteenth Century Britain," English Historical Review 128 (2013): 813, 828-29.

38. HL, ST 57 Vol. 2, fol. 149.

39. HL, ST 57 Vol. 2, fol. 72; ST 58 Vol. 3, fol. 4. For Brydges's interest in horses, see Baker and Baker, Chandos, 99, 129, 202-4. For Mead, see Graham, Corruption, 154-55, 157, 162. 40. HL, ST 58 Vol. 9, fol. 258.

41. HL, ST 57 Vol. 4, fol. 93; Graham, Corruption, 64-65, 140-44.

42. Carol Benedict, Golden-Silk Smoke: A History of Tobacco in China, 1550-2010 (Berkeley, Calif., 2011), 113, 115-17; Jordan Goodman, Tobacco in History: The Cultures of Dependence (London, 1993), 68-75, 81-84. 
One of his agents in Lisbon, Charles Medlycott, sent at least a pound of Brazilian snuff in 1709 and emphasized that it was "a commodity very scarce to be got here good, they have so many ways and tricks to mix it." 43 The comment served to advertise both the quality of the snuff he had sent and the taste he had displayed in choosing it. This was clearly important, because Brydges was alert to the quality of his snuff, and he complained later that year that a further shipment would be required, "[because] that you sent before hath quite lost its flavour, and is turned as brown as a nut." Both Morrice and Medlycott also sent "sweet waters" or perfumes, which Holly Dugan has shown were equally subject to aesthetic judgment. In 1709 Medlycott noted that his own supplies were "double distilled, and the best that I could get." 44 Brydges's agent in the Baltic, Francis Stratford, sent him "our own Hamburg manufactures as smoked beef, hams and old Hock" and used the opportunity to show his judgment by noting that it was too late in the season for sturgeon or smoked beef, "but you shall be sure of a provision of the first that is fit to be sent away." 45 These letters all hint at the role played by exchanges of food, snuff, and other consumables in creating a sense of shared tastes, interests, and obligations between Brydges and his officials, and thus trust, heightened by the aesthetic qualities of the objects sent.

\section{产}

Fortunately Brydges and his household consumed large enough quantities of wine to demonstrate how this process operated in practice. Wine was enjoyed as an intoxicant and social lubricant, as described in the next section, but it could also carry important cultural overtones of taste, judgment, and even political allegiance. French wines were seen as unpatriotic in this period, for example. They were replaced with Portuguese wines, especially between December 1713 and January 1714, when the Tory ministry tried to push through Parliament a bill to remove the high duties put on French wines by the previous Whig ministry. ${ }^{46}$ As this section will show, gifts of wine could thus be culturally coded, in the same way that new colonial commodities

43. HL, ST 57 Vol. 2, fol. 173; ST 58 Vol. 3, fol. 237; Vol. 7, fol. 42; Vol. 11, fol. 141; Graham, Corruption, 146-48.

44. HL, ST 57 Vol. 1, fol. 228; Vol. 2, fol. 82; Vol. 3, fol. 62; ST 58 Vol. 2, fol. 43; Vol. 3, fol. 237; Holly Dugan, The Ephemeral History of Perfume: Scent and Sense in Early Modern England (Baltimore, 2011).

45. HL, ST 57 Vol. 1, fol. 98; Vol. 2, fol. 83; Graham, Corruption, 87, 97-98, 103.

46. Motoko Hori, "The Price and Quality of Wine and Conspicuous Consumption in England 1646-1759," English Historical Review 123, no. 505 (2008): 1457-59, 1463-66; Charles Ludington, The Politics of Wine in Britain: A New Cultural History (Basingstoke, U.K., 2013), 96-99, 209-10; Hancock, Oceans of Wine, 337-92; Perry Gauci, The Politics of Trade: The Overseas Merchant in State and Society, 1660-1720 (Oxford, 2001), 234-70; John V. C. Nye, War, Wine, and Taxes: The Political Economy of Anglo-French Trade, 1689-19oo (Princeton, N.J., 2007), esp. 20-59. 
such as sugar, rum, tea, and coffee increasingly represented imperial patriotism. 47 Yet wine was also an aesthetic experience that could allow participants to exhibit their sophistication, judgment, and connoisseurship. Jacobsen notes that "knowledge of the correct way to consume such wines was ... important, and transformed a common Italian commodity into a prized luxury." 48 There is no question that Brydges was alert to such concerns-he complained, for example, that some wine he had been sent by a hospital contractor was "but very indifferent, [and] by no means worth the trouble I have been at to get it out of the Custom House." His letters demonstrate that he and his agents highlighted issues of taste and quality to increase the impact of such gifts and to strengthen the sense of shared interests that built trust. 49

The sheer volume of wine that flowed, quite literally, through Brydges's networks is remarkable. Morrice sent several hogsheads of Portuguese wine as gifts practically every year between 1707 and $1711 .^{\circ}$ Medlycott promised him in 1710 that "if the next vintage proves good, [I] will send you some wine of this country, which will be to your liking." 51 Sweet, Cartwright, and Stratford sent large parcels of wine as gifts or acted as Brydges's agent for larger orders, illegally smuggling a shipment of French wine into Britain in 1707 , for instance, by concealing it in Hungarian casks. ${ }^{52}$ The next year Brydges hired Drummond to supply the British prisoners in France with their pay, and he used this opportunity to procure shipments of French wine from his agents in Paris and Bayonne. 53 Hallangias offered to secure "some good wines from Liege" in July 1707, though his confidence in his own judgment failed him here, too, and he was forced to ask "which Your Honour loves most, champagne, burgundy or Hermitage," demonstrating how important it was for Hallangias that his gifts meet with Brydges's approval.54 Initially Senserf only transshipped wine bought for Brydges by other agents such as Stratford, but he too began to purchase consignments for Brydges directly, sending over three hogsheads in August 1710 just after the new Tory ministry came to power and adding that Brydges would now be "extremely well provided to drink the health of old and new ministry, or old and new Parliament." 55

47. For other examples of consumables and cultural resonance, see Troy Bickham, "Eating the Empire: Intersections of Food, Cookery and Imperialism in Eighteenth Century Britain," Past and Present, no. 198 (2008): 71-109, and the correction in Stobart, Sugar and Spice, esp. 55-59, 193, 269.

48. Jacobsen, Luxury and Power, 64, 68, 123-24, 126, 188.

49. HL, ST 57 Vol. 9, fol. 53; Baker and Baker, Chandos, 176, 188-93; Ludington, Politics of Wine, 100-103.

50. HL, ST 57 Vol. 2, fols. 13, 157, 172; Vol. 4, fols. 36, 93, 147; ST 58 Vol. 2, fols. 43, 149; Vol. 5, fol. 239; Vol. 7, fol. 236; Baker and Baker, Chandos, 188.

51. HL, ST 58 Vol. 4 , fols. 58-59.

52. HL, ST 57 Vol. 1, fols. 42-43, 109; Vol. 2, fols. 42, 102, 159, 191, 195; ST 58 Vol. 1, fols. 71, 73, 81, 86-87, 98, 107, 157; Vol. 2, fol. 257; Vol. 7, fol. 207.

53. HL, ST 58 Vol. 4, fols. 33, 151-52, 159, 210-11.

54. HL, ST 58 Vol. 2, fol. 20.

55. HL, ST 57 Vol. 2, fol. 109; Vol. 3, fols. 99, 131, 258; Vol. 4, fols. 11, 63, 88, 177, 231; ST 58 Vol. 1, fols. 81, 107; Vol. 6, fol. 180; Vol. 9, fol. 43. 
Because the quality of the wine mattered as much as the quantity, the agents took particular pains to advertise their judgment. Morrice noted in 1710 that "the wines last vintage proved the worse that have been known, but I hope the two casks sent you will be as good as I hope, being the very best that could be had." 56 Medlycott likewise noted that "the wines this year are scarce and few good, 'tis the best I can get and hope will arrive safe and prove to your likening," as indeed it did.57 As with commodities such as textiles, Brydges therefore did not distinguish much between financial integrity, commercial ability, and aesthetic judgment, relying on his friends and agents to deliver all three. New agents could be incorporated slowly into these networks, in the same way that George Murray was, and likewise graduate from private to public roles. In 1707, for example, Drummond introduced Brydges to a Scottish wine merchant in Rotterdam named Gilbert Black, a private contact of long standing. ${ }^{58}$ Initially their contact was purely commercial, and Brydges even asked Sweet to check on the prices that Black had charged him. But by September 1711 his trust in Black's judgment was absolute, and he therefore urged Black to send over 100 flasks of champagne and Burgundy, sight unseen and worth about $£ 100$, if he judged them to be "extraordinary good." 59 As trust increased, Black was also slowly drawn into Brydges's Pay Office networks, and by July 1711 he began to play an important role in supplying money for the army in place of Drummond.60

The process from the perspective of Brydges's agents can be recovered from the letters of Charles Medlycott, which demonstrate that Brydges was only one of a number of patrons and personal contacts who received gifts of wine and snuff from Medlycott, who took care to tailor the type of gift and its quality to individual circumstances. "I have sent to my patrons many presents," he noted in February 1710, "[and] few of them prove well, through the roguery of one or other." Several even went missing in transit, but he nevertheless persisted because such gifts were vital. For example, having left his children in the care of William Whitfield, rector of St. Martin's Ludgate in London, he shipped over in April 1710 a hogshead of "the best red wine this country affords" and a basket of chocolates, noting "[we have] different palates, I send[ing] for mine out of England, you from Portugal." ${ }^{61}$ In return Whitfield helped Medlycott find a new clerk for his public business in July 1711. He also acted as one of his sureties for $£ 1,000$ in December 1711, when the Treasury told Brydges to demand

56. HL, ST 57 Vol. 4, fol. 36; ST 58 Vol. 6, fol. 117.

57. HL, ST 57 Vol. 4, fol. 34; ST 58 Vol. 5, fols. 234, 239.

58. HL, ST 58 Vol. 1, fols. 46, 92; National Records of Scotland, Edinburgh, $\mathrm{GD} 24 / 1 / 464 / \mathrm{A} / 26,31,38$.

59. HL, ST 57 Vol. 2, fol. 114; Vol. 5, fol. 239; ST 58 Vol. 3, fols. 59, 78; Vol. 10, fols. 43-44.

6o. Graham, Corruption, 135, 205.

61. C/2922, Medlycott to Whitfield, February 1, April 17 and 28, 1710, n.s. Northamptonshire Record Office, Northampton (hereafter NRO). 
financial securities for good behavior from his agents. ${ }^{62}$ Further gifts of Indian and Italian damask and "a hogshead of the best Barabar, which I hope will arrive safe ... for 'tis extraordinary wine," went to his patron George Nevill, first Baron Abergavenny, a midranking Whig politician who promised to provide a church living for Medlycott's son and kept him abreast of the political changes at home. ${ }^{63}$

Other gifts went to Medlycott's brother James, a Tory politician who looked after his public and private business in London and even lobbied Brydges several times on Medlycott's behalf. "If I succeed, I shall acknowledge and owe your favours," Medlycott wrote to James on one occasion, "and will send you wine yearly." 64 His other brother, Thomas, was less helpful, but Medlycott used the same techniques. "If you are so fashionable to take snuff... I have sent you ... a pound of the best Brazil, just come from thence," he wrote to Thomas, "[and] as 'twas formerly very scarce, so 'twas esteemed an acceptable present among you great people." 65 Other gifts went to the War Office, which shared responsibility with Brydges for Medlycott's public role as commissary of the stores, and which proved particularly tardy about giving orders. To help matters along and build trust and mutual obligations, Medlycott sent deputysecretary Samuel Lynn in August 1713 "two chests of the finest and best Brazil sugar this country affords ... [and] 2 pounds of the best burnt snuff and 6 quart-bottles of orange-flower water." 66 Learning from his earlier experience with Brydges, he did not send more, explaining that any more would go off before it could be used.

Medlycott reserved his most extensive gifts for Brydges and for Brydges's deputy in London, William Sloper, who handled matters such as salary and had sometimes left long delays in payment. To ease these delays, Medlycott sent a pound of "best Brazil snuff” in November 1710, via Sloper's brother-in-law Col. Thomas Vesey, as well as a hogshead of good Barabar wine and a further hogshead of Laverdie in January. ${ }^{67}$ "If you have an opportunity to offer it, and you think it won't be taken amiss," he told his banker, "I would be glad to give a hogshead of good wine yearly to

62. NRO, C/2922, Medlycott to Whitfield, July 20 and October 16, 1711, n.s.; Medlycott to James Medlycott, December 29, 1711, n.s.

63. NRO, C/2922, Medlycott to Whitfield, February 1, 1710, n.s.; Medlycott to Lord Abergavenny, June 20, 1710, July 11, 1710, January 16, 1711, June 8, 1711, April 19, 1712, n.s.; Medlycott to Le Hunt, May 20, 1711. See also HL, ST 58 Vol. 3, fol. 31. For Abergavenny (also known as Baron Bergavenny), see Geoffrey S. Holmes, British Politics in the Age of Anne, rev. ed. (London, 1987), 425.

64. NRO, C/2922, Medlycott to James Medlycott, February 1, 1710, January 17, 1711, November 26, 1711, December 29, 1711, n.s.

65. NRO, C/2922, Medlycott to Thomas Medlycott, November 7, 1712, n.s.; Medlycott to Warner, November 7, 1710, n.s.; Medlycott to James Medlycott, January 17, 1711, April 12, 1712, n.s.

66. NRO, C/2922, Medlycott to Lynn, May 24, 1712, August 26, 1713, September 8, 1713, October 11, 1713, n.s.; Medlycott to James Medlycott, June 22, 1713.

67. NRO, C/2922, Medlycott to Warner, November 7, 1710, n.s.; Medlycott to Sloper, November 9, 1710, January 17, 1711. 
Mr Sloper." 68 In practice this was a fruitless endeavor, because Medlycott had aligned himself with the Whig faction among the British fiscal-military officials in Lisbon, whereas Vesey had thrown his weight behind Thomas Morrice and the Tory faction and was writing poisonous letters to Sloper and Brydges behind Medlycott's back. ${ }^{69}$ For the moment this remained a private inconvenience, but when Medlycott was elevated to serve as Brydges's deputy in Gibraltar in April 1712, he feared that this mysterious feud would obstruct his public duties, and he therefore asked James Medlycott to intervene. "The headman of that office Mr Sloper (I have sent him several presents), for what reason I know not, but on all occasions, I believe, has opposed my interest," he told his brother in April 1712, "which, as you pass, by discoursing with him, you'll easily find out, [since] 'tis very necessary we should have a right understanding together."70 Two years later in January 1714, Medlycott sent a further gift to Sloper. "The wines proving this year better than usual," he sent a whole hogshead of "very good, rich white wine," a Calcavella, adding that "I heartily wish it may prove to your liking, and you[r] health and pleasure in drinking it."71

Indeed, this gift of Calcavella white wine demonstrates extremely well how Medlycott tailored his gifts to individual circumstances. Tory officials such as Sloper and Lynn were only informed that it was wine of the highest quality, with Lynn being told that it had been bought "from one [Mr.] Pitt, who pretends to be known to you ... I heartily wish you well to drink it, and your acceptance of this trifle will be in addition to the many favours already received." 72 To Charles Robartes, second Earl of Radnor and another midranking Whig patron, he similarly presented a hogshead of Laverdie, "having heard your Lordship commend these country wines, which have this year proved good... Better has not crossed the sea this year."73 However, to burnish his political credentials with Thomas Wharton, first Marquess of Wharton, who had led the attack on the Tory French Commerce Bill, he wrote that he had heard that "these country white wines are at present a fashionable drink, especially among those worthy opponents of the French bill." He sent a hogshead of "the best Calcavellas (being neat and pure) ... which I beg you'll do me the honour to accept, though but a small acknowledgement for the many favours you were formerly pleased to confer on me." 74 The gifts of wine were therefore consciously embedded into a much wider context and possessed political qualities that supplemented their mere monetary value.

68. NRO, C/2922, Medlycott to Warner, April 17, 1710, n.s.

69. Graham, Corruption, 146-49, 221-25.

70. NRO, C/2922, Medlycott to James Medlycott, April 22, 1712, n.s.

71. NRO, C/2922, Medlycott to [?Sloper], January 20, 1714, n.s.

72. NRO, C/2922, Medlycott to Lynn, December 16, 1713, n.s.; Medlycott to Wyndham,

December 29, 1713, January 2, 1714, n.s.; Medlycott to Sloper, January 20, 1714, n.s.

73. NRO, C/2922, Medlycott to Radnor, January 21, 1714, n.s. For Radnor, see Holmes, Politics, 226, 265, 431.

74. NRO, C/2922, Medlycott to Wharton, December 29, 1713, n.s. For Wharton, see Holmes, Politics, 240-41. 
This in turn helps to explain how Brydges used gifts of cider as unlikely instruments to bolster his own networks. Sixteen dozen bottles, or two hampers, were sent, for example, to James Stanhope, the commander-in-chief of the allied forces in Spain, in 1708.75 Other gifts went to various solliciteurs-militair in Amsterdam, to Brigadier George Wade in Barcelona, and to his trusted agents John Drummond and Thomas Morrice, the last two in return for wine they had sent him. ${ }^{76}$ As with gifts from his own agents, Brydges was concerned to stress the quality of it, noting to Stanhope that "I have taken the liberty to send you the best cider I could get ... [and] I presume the heat of the climate where you are will not render it less so there." 77 Cider also carried other, equally important, political resonances. Since the 1650 s the production of fruitor grain-based alcohol had been seen as a patriotic act of import substitution. Despite flagrantly disregarding such matters when he bought French wine, sending gifts of cider allowed Brydges to make a strong statement about his own patriotism. ${ }^{78}$ Moreover, English cider production was centered in the southwest of England, including his own county of Herefordshire, and his gifts of high-quality cider made a flattering statement about the care he had lavished on the selection, transport, and storage of this notoriously temperamental drink.79 Alcoholic beverages such as wine and cider therefore had important cultural and political overtones that Brydges and Medlycott tailored to their audiences, reinforcing the private connections within public networks by strengthening the sense of shared interests that created trust.

\section{害}

As noted above, Phil Withington and others have argued that examining not just the changing patterns of alcoholic consumption but also its rituals and dynamics can shed important light on the nature of sociability and company in early modern Europe, and, incidentally, on the interpersonal connections that created trust within commercial networks. Brian Cowan has noted, for example, that Brydges enjoyed a

75. HL, ST 57 Vol. 2, fols. 77, 80-81; ST 58 Vol. 3, fol. 224.

76. HL, ST 57 Vol. 1, fols. 80-81; Vol. 2, fols. 109, 164; Vol. 4, fol. 147; ST 58 Vol. 1, fol. 46; Vol. 7 , fol. 239. In 1721 he presented forty dozen bottles of cider to Henry Davenant for purchasing pictures for him in Italy, as well as twenty dozen of ale, two dozen of citron water, and six bottles of Irish whiskey: Baker and Baker, Chandos, 81. For his links to Wade, see Graham, Corruption, 144 .

77. Stanhope MS, U1590/O138/2, Brydges to Stanhope, September 25, 1708, Centre for Kentish Studies, Maidstone, U.K.

78. John Chartres, "No English Calvados? English Distillers and the Cider Industry in the Seventeenth and Eighteenth Centuries," in English Rural Society, 1500-180o: Essays in Honour of Joan Thirsk, ed. John Chartres and David Hey (Cambridge, 1990), 322-30; Vittoria di Palma, "Drinking Cider in Paradise: Science, Improvement and the Politics of Fruit Trees," in A Pleasing Sinne: Drink and Conviviality in Early Modern England, ed. Adam Smyth (Woodbridge, U.K., 2004), 161-77.

79. Chartres, "No English Calvados?" 313-22, 330-40. 
"coffeehouse sociability" as a young man between 1697 and 1702, visiting numerous coffeehouses in one day and using them as an opportunity to introduce himself to useful contacts at the Royal Society. ${ }^{80}$ Cowan argues that, after Brydges was made paymaster of the forces in 1705 , his "increasingly distant relationship to the world of coffeehouse sociability reflected his newly secure status as a prominent virtuoso patron.... he no longer needed to curry favour." 81 This section of the essay will show that the focus of Brydges's sociability had shifted toward forms of private sociability centered on the consumption of wine, which afforded opportunities to reinforce his personal relationships with other groups of people and to build the trust he needed for his public and private networks. Private sociability offered chances for Brydges and his agents not only to display connoisseurship, with the advantages described above, but also to engage in the sociable rituals of toasting and drinking "healths" that helped to strengthen trust among the assembled company.

Alcohol was an invariable adjunct whenever Brydges and his agents gathered, as were the rituals that went with it. When Cartwright arrived in Holland in October 1706, for example, he was introduced by Brydges's agent Francis Stratford to useful commercial contacts such as Senserf, Drummond, and Abraham Romswinckel. ${ }^{82}$ "I was with some other good friends of yours very handsomely entertained yesterday at The Hague by Captain Cartwright, where your health was not forgot," Drummond told Brydges. He pledged to serve Cartwright "in everything that may be in my power, with that affection and heartiness which I owe to your friendship and recommendation." In November 1709 he noted that he had drunk Brydges's health with several officers of the army, and Brydges wrote back that he was greatly obliged for the compliment. ${ }^{83}$ Earlier that year, Decker wrote that he had purchased for Brydges a quantity of "the best old hock that is, not only in Holland but I may say in Europe." 84 To reinforce this, he noted that "Mr Drummond and other friends have tasted, and all judge that they never found any better. ... Mr Senserf, with who I have had the honour to drink your health, assures you of his respect, and so does J[ohn] Drummond." In June 1712, Brydges's cousin Humphrey Walcot went out to Amsterdam to replace Sweet, and he was also wined and dined by Senserf and others. "We were merry and remembered you more than once in good champagne and claret," Senserf noted to Brydges, killing two birds with one stone by stressing that the compliment to his patron had been done in a way that also did credit to the taste and sensibility of the assembled company. 85

80. Cowan, Social Life of Coffee, 108-10.

81. Cowan, Social Life of Coffee, 110.

82. HL, ST 57 Vol. 1, fols. 40, 56; ST 58 Vol. 1, fols. 101-2, 103. For Romswinckel, see Graham, Corruption, 84, 103.

83. HL, ST 58 Vol. 5, fol. 49; ST 57 Vol. 3, fol. 116.

84. HL, ST 58 Vol. 4 , fol. 97.

85. HL, ST 58 Vol. 12, fols. 70, 80, 119. Amanda Lahikainen has suggested to me that Senserf might merely have made this up, to fulfill the expectations of politeness, and that this 
The quality of wine could therefore be important to the process of sociability, since it provided opportunities for displaying the discernment that Brydges valued. One friend was offered a diametrically opposed but perhaps equally flattering compliment in 1702, when he was told that several of his friends had repeatedly drunk his health, "to the no little hazard of our own, the wine being very bad." 86 But just as important were the rituals of toasts and sociability that helped to build personal connections between key actors in Brydges's network and otherwise reinforce a sense of friendship and trust between them. Brydges told Sweet in 1710, for example, that he had recently dined with Murray's father in London, who "was so kind as to eat a bit of mutton with me; you may be sure we did not fail your health." 87 The following year he dined with several of Drummond's friends at his house at Sion Hill in London, "where we shall not fail your health, nor our wishes we had you with us." 88 When his agent Hallangias negotiated a financial arrangement with a solliciteur-militair to the Saxon regiments, alcohol was an invaluable aid. "[He] was in the beginning very stiff, certainly made up by somebody," Hallangias told Brydges, "[but] after two hours talk, and two bottles of champagne betwixt us emptied, he complied at last to come to the desired terms." 89

By the same token, failures of sociability or conviviality could demonstrate or amplify breaches in the trust that held these networks together. Hallangias noted in November 1707 that he had fallen out with Sweet, due to his impossible behavior, most recently "when yesterday Mr [Adam] Cardonnel and several English gentlemen did me the honour to take a dinner at my house; Mr Sweet only found or made excuse to be absent." 90 When Brydges's nephew Col. James Leigh arrived in Portugal in 1709, he found Medlycott and Morrice violently at odds, and both in search of allies to help undermine the other. ${ }^{91}$ Sociability and hospitality were decisive factors in enabling Leigh to choose sides. He complained to Brydges that he had been snubbed when waiting on Morrice- "I do not say amiss in waiting on him, for he has either no chairs or fears spoiling them, for he never asked me to sit down, or dine with him"-though Morrice claimed in his letters that he had frequently dined with Leigh "and offered him the convenience of his lodging, entertainment and all other things he might have occasion of." 92 Leigh contrasted this with his treatment by Medlycott, "[who] has

nevertheless shows the strength of such expectations in relations between Brydges and his agents.

86. Add. MS 38852 , fol. 6 , British Library.

87. HL, ST 57 Vol. 3 , fol. 246; ST 58 Vol. 6, fols. 52-53.

88. HL, ST 57 Vol. 5 , fol. 124.

89. HL, ST 57 Vol. 1, fol. 255; ST 58 Vol. 2, fols. 98, 100, 130, 131, 139-40; Graham, Corruption, 119.

90. HL, ST 58 Vol. 2, fols. 164-65. Cardonnel was the Duke of Marlborough's private secretary and a close contact of Brydges: see Graham, Corruption, 102-5, 127.

91. See above, note 70.

92. HL, ST 57 Vol. 2, fols. 172, 173; ST 58 Vol. 4, fol. 1; Vol. 6, fols. 6, 66; Vol. 7, fol. 110; Vol. 10, fol. 39 . 
been always very civil to me, he would never let me lodge anywhere but in his own house." Leigh therefore took the side of Medlycott, who later presumed on this link to lobby Leigh to provide an ensign's place in his regiment for his son.93

\section{额}

Connoisseurship, collecting, consumption, and company were therefore all linked in the early eighteenth century because they helped create trust in a society that was based heavily on the operation of personal networks for public and private ends. Indeed, it is difficult to determine where one stopped and the other ended. Brydges continued to draw on these networks long after he left the Pay Office in August 1713. Henry Cartwright joined the Victualling Office after he left Brydges's service, for example, but continued to exchange favors, correspondence, and gifts, including a shipment of snuff and exotic eggs in August 1726. "The first I take to be extraordinary good of the kind," Brydges wrote, "and the latter will be a very great curiosity if they can be brought to hatch." $94 \mathrm{He}$ continued to send friendly letters and news to Jan Hallangias, who sent wine and Westphalian hams in return. 95 In July 1734, a reconciliation with Benjamin Sweet was sealed with a gift of venison and one of pineapples from Brydges's greenhouse at Canons: "they are the first my garden has produced this year," he wrote, "and I desire your acceptance of them."96 Although the act and process of consumption could therefore continue to be appreciated by Brydges and his agents for the sheer aesthetic pleasures of connoisseurship and company, they also bolstered the sense of mutual obligation, personal connections, and shared interests that built up trust within networks in the early modern period.

This essay has therefore suggested the ways in which large parts of the scholarly literature on early modern connoisseurship, collecting, consumption, and company might be brought into fruitful integration by showing how individuals such as Brydges and his agents used the act of consumption to build trust within the networks that held society together. This is not to suggest that Brydges and his agents were purely instrumental or artificial in the way that they approached the act, but simply that, since consumption, company, and connoisseurship were an inevitable part of life, they were approached in ways that drew on and served to reinforce the personal relationships between those involved. Even more broadly, by highlighting the very blurred line between public and private networks in this period, this essay has also suggested that the literature on state formation and political change requires reassessment. Public officials in the early eighteenth century clearly continued to rely on private individuals to help implement public policy, and even public officials were

93. NRO, C/2922, Medlycott to Col. Leigh, August 12, 1712, n.s.

94. HL, ST 57 Vol. 28, fol. 259; Graham, Corruption, 234-35, 237.

95. HL, ST 57 Vol. 14, fol. 400; Vol. 29, fol. 277; Vol. 40, fol. 151.

96. HL, ST 57 Vol. 44, fols. 230, 233; Graham, Corruption, 237-38. 
drawn into personal relationships with a wide range of contacts, as the necessary condition for making public business work effectively. The challenge for officials such as Brydges was to use this process strategically and efficiently, in ways that aligned public and private interests, in effect making corruption simply an instrument of state. "Corruption and patriotism," I have argued elsewhere, "were therefore two sides of the same coin." 97 This essay has suggested that, for Brydges and his agents, wine, snuff, cider, and even Westphalian hams were an integral part of this process.

This research was funded by a Doctoral Scheme Award from the Arts and Humanities Research Council, with additional funding from the Reynolds Fund at New College, Oxford, and a Postdoctoral Fellowship from the British Academy. I am grateful to all these bodies for their support. I would also like to thank David Parrott, Carole Taylor, and Amanda Lahikainen, and Susan Green and the reviewers at the $H L Q$, for offering their comments and advice on this essay.

AARON GRAHAM is the author of Corruption, Party, and Government in Britain, 1702-1713 (2015) and the co-editor, with Patrick Walsh, of The British FiscalMilitary States, 1660-c.1783 (2016). He is a Leverhulme Early Career Fellow at University College London. 
